NAMES, Vol. 37, No. 2 (June 1989)

\title{
A Century of Montana History in Her Placenames
}

\section{Roberta Carkeek Cheney}

\begin{abstract}
The placenames of Montana are a rendering of its local history in poetic form. Echoes of the men and women who came to stay mingle with the echoes of those who came but did not stay. The Indian on a buffalo hunt; the fur-trapper building his trading post; the cattleman riding in the dust kicked up by a thousand longhorns; the miner with his dream of wealth; the dryland farmer praying for rain; the lonesome settlers from other lands and other states; the railroaders pushing westward; and the newcomers with industry and oil-each one has added to the history of the region, and that history can be read in the stories of Montana's placenames.
\end{abstract}

$2 * 2 * 2 * 2 * 3$

Montana's hundred year history is colorfully reflected in her placenames. The prospectors came and named their camps Gold Creek, Silver Star, and Copperopolis. Later miners added Granite, Coalstrip, Cinnabar, Sapphire, and Ruby. Cattlemen trailed huge herds in from Texas and turned their brands into placenames like Two Dot, Mill Iron, and Seventy-nine. The broad plains and free land of Montana beckoned to people from other countries who brought names with them to plant in the strange new land: Zurich, Amsterdam, Glasgow, Inverness, and Silesia Springs. Settlers from other states thought wistfully of towns they had left behind and called their new homes Amherst, Ashuelot, Potomac, and Corvallis.

The railroaders laid tracks over the trackless prairies and pushed through mountain ranges to cross the state. They named the stations as they were established. Usually these names were chosen to honor a railroad official or a member of his family. Billings, Harlowton, Maudlow, and Geraldine (Rockefeller) were a few of them.

Indian names are a familiar part of Montana's history. Many names come from tribes, e.g., Flathead, Crow, Kootenai, Bannack (Bannock), Blackfoot, Kalispell, and Pondera (Pend d'Oreille). The towns of Charlo, Pablo, Lame Deer and Victor were among those named to honor In- 


\section{Roberta Cheney}

dian chiefs. Red Lodge, Lodge Grass, and Deer Lodge describe their homes. The name Deer Lodge, now a county, comes from a settlement called Lodge of the White-Tailed Deer, a phrase which captures the Indian sense of residence. There is also Pipestone Springs where the Indians came to get the very fine clay to make their pipes and Painted Robe where the colors were obtained to paint their robes.

Forts played an important part in Montana's early history, and there are over fifty placenames using the term Fort. Some of them were military forts; most of them were trading posts, but even the latter were fortified against Indian raids. Fort Shaw and Fort Benton have survived as town names.

Border towns combine the names of both states: Monida, Wyola, and Mondak. Mondak grew up in prohibition days. Dakota was politically "dry" but the citizens were thirsty. Montana was "wet" and eager to sell liquor to the Dakotans; so the saloons were all just over the line in Montana, and the grocery stores, churches, and most of the residences were on the Dakota side.

There are more names of French origin than of any other single ethnic group. The early French trappers left their mark on the maps of Montana. They left their names in the Indian tribes as they married the native girls and fathered half-breed children, who were later to be instrumental in settling and naming areas of the state. Belleview, Bonaccord, Argenta, Valleux, Chouteau, Teton, Wibaux, Dupuyer, and many others are obvious remnants of French influence. Dupuyer in Pondera County came from the French word depouilles, which trappers and explorers used to describe the back fat of the buffalo, a delicacy esteemed by both Indian and white men.

Dagmar is the trade center for a community of Danish-Americans who first named their town Dronning Dagmars Minde in honor of Queen Dagmar of Denmark. Inverness is on the Highline, west of Havre, and was named by "Scotty" Watson for his home town in Scotland, though its topography bears little resemblance to the inlet town that separates Loch Ness from the ocean. Glasgow was named for another town in Scotland. It began as a siding on the Great Northern Railroad and consisted of four tents which housed three saloons and a restaurant. By 1889, Mrs. Frank Fryburg had started a Sunday School which she held first in a boxcar, then in a schoolhouse, later in the Kewis Brothers store and finally in the little Methodist church which was built in 1890 . 
The early day Jesuit missionaries left an imprint in DeSmet, Ravalli, and the thirteen missions that they established and named. In Montana, it is St. Mary, St. Labrae, St. Regis, St. Xavier, and St. Ignatius with no Spanish influence to call them San or Santa as in California. The Catholic missionaries came to minister to the Indians long before there were any towns. They established missions which later became towns and carried the names to honor Catholic saints. Missionaries from other denominations came later and ministered to already established communities, so they had little influence in the naming process.

There are not as many cowboy names as one would expect, not even a town named for the most famous Westerner, artist Charles M. Russell. We do have Roundup, and roundups were a vital part of Montana's early economy. During the open range days, great herds of cattle were turned loose to graze, but twice a year, spring and fall, roundup camps were established, and cowboys were sent out to ride circle and bring in the cattle to be branded or to be shipped to market. John Murphy's ranch encompassed all the land that is now Golden Valley County. He brought his cattle in and established headquarters there in 1879; so he chose 79 for his brand and it became a town name, too. Two Dot Wilson put his brand on a lot of cattle and a town. He put one dot on the shoulder and one on the hip of each critter he owned, and it was hard for the cattle rustlers to remake that brand.

Rag-tags from the Civil War armies came to Montana and left their imprint in the names: Confederate Gulch, Virginia City, Unionville, and Yankee Flats. When Marcus Daly laid out the city that was to smelter the ore from the Butte mines, he wanted to name it Copperopolis, and surely that name would have been appropriate, but a little mining camp with a post office granted in 1881 had that name. So he named his new town for one of the most promising and productive mines in Butte, the Anaconda. Michael Hickey, an Irish miner and ex-soldier from the Civil War, had read an editorial by Horace Greeley stating that Grant's army was encircling Lee's forces like a giant anaconda snake. "That word and image stayed with me," Hickey said, and when he struck a rich vein of ore and had to give the mine a name, he chose Anaconda. Thus, the name that was to become the giant in Montana and in mining circles around the world was neither historic nor descriptive but mere chance.

There were and are interesting associative names, but sometimes not of towns. There was Hog 'em, Jitney, the Jaw-Bone Railroad, and Whoop- 


\section{Roberta Cheney}

up Trail. In 1870 the United States government outlawed selling whiskey to the Indians, and the marshals set out to see that the law was obeyed. However, many fur traders regarded whiskey as the first requisite of their business. Where whiskey was, there the trade was, so they went up into the less restricted territory across the Canadian border and built their trading posts. One of the first of these was Fort Hamilton, but the flourishing business soon led to its rechristening as Fort Whoop-up. So the North country came to be known as Whoop-up country, and the two-hundred-mile trail that led from there to Fort Benton was called the Whoop-up Trail. After the Canadian mounties put an end to the whiskey runs, the trail was used as a freight road and supply line for more acceptable goods, but the name remained. To balance the scales, there was also a line camp on the way that was called Sober-up.

Diamond City in what is now Broadwater County once had a population numbering in the thousands. It was called the wealthiest, gayest, toughest place in Montana. The name is a relative description because it came, not from any diamonds found there, but because the four big claims of gold were connected by footpaths and formed the pattern of a diamond.

Bull Springs and Bull Hook Bottoms got their names because cattle would get bogged down in the marshy ground in northern Montana with only their heads sticking out and usually could be retrieved only by using bull hooks. When the railroad came through and decided to put a station at Bull Hook Bottoms, the officials insisted upon a change of namea more dignified one. Several of the settlers got together and decided to name the town after their hometown in France. So Le Havre (meaning "the harbor") crossed the ocean and became Havre, Montana.

The most colorful names in Montana are the descriptive ones. Lewis and Clark chose many of them as they explored and mapped the territory. They saw the morning sun reflected on the mountains and called them Shining Mountains. We were Land of the Shining Mountains until Bud Guthrie came out with his book, The Big Sky, and that name caught on as an appellation for Montana. The mountains were officially named The Rocky Mountains, and rocky they certainly are. The name first occurs in the 1752 journal of Jacques Legardeur de Saint-Pierre as "Montagnes de Roche," but may have come to Lewis and Clark more directly as a translation of the Cree name As-sin-wati. The Great Falls of the Missouri, first named by Lewis and Clark, was later to become a town name, 
and the big horn sheep that the explorers found in Eastern Montana gave rise to their name for a mountain range. But Lewis and Clark also named places for members of their party, Pryor Creek for Sgt. Nathaniel Pryor, a member of the expedition, and Pompey's Pillar for Sacajawea's little son Baptiste, affectionately called "Little Pomp" by Clark. A town that later grew up nearby took its name from the pillar of rock on which Clark had carved his initials and the date July 25, 1806.

Perhaps Lewis and Clark's most interesting naming feat was of the three rivers they found to be making up the Missouri. Being politicians as well as explorers, they named them for Thomas Jefferson, their president and supporter; Albert Gallatin, Secretary of the Treasury, who made out their pay checks; and James Madison, Secretary of State. They had a new problem when they followed the Jefferson and found it, too, divided into three streams, so they named them for the "three cardinal virtues" of President Jefferson: Wisdom, Philosophy, and Philanthropy. The old prospectors who came along half a century later could not read maps very well, let alone pronounce philosophy and philanthropy, so the names were changed to the Ruby, the Beaverhead, and the Big Hole-all descriptive of the area. The name Wisdom did survive in a town name, and a nearby stream is called Wise River. Beaverhead was a famous name because it referred to a big rock outcropping shaped like the head of a beaver which Sacajawea and her tribe used as a landmark. Besides the river, there is a town of Ruby and the Ruby Mountains, although all of them are really misnomers because the stones found there and originally thought to be rubies turned out to be garnets. The explorers named two other rivers for members of the President's Cabinet, the Smith and the Dearborn.

Meriwether Lewis seemed to be a bit more romantic and named two rivers for the girls back home. The Maria's River is in northern Montana, and the Judith in Central Montana. The Gates of the Mountains describe a spectacular break in the mountains where the Missouri River rushes through. Two rivers, the Clark Fork of the Columbia and the Clark's Fork of the Yellowstone, were named to honor William Clark. The name of one county, originally called Edgerton for the state's first Territorial Governor, was changed in 1867 to Lewis and Clark.

The town near the place where the three big rivers come together to form the Missouri is appropriately called Three Forks; nearby is Trident where the cement company uses a devil's pitchfork as a logo with the 
Missouri River representing the handle and the three feeder rivers the tines.

The rivers and streams, being here before people, were often given descriptive names. Missouri came from an Indian word meaning "Big Muddy." The Milk River drains an area in Canada where a white silt colors the water; Yellowstone was called Roche Jaune by the early French explorers to describe the yellow rocks found along its banks. Translated to English and given to the national park as well as the river, it is one of our most widely known names. The Tongue River heads in a Wyoming mountain where a giant "tongue" is outlined by a rock formation and trees. Powder River is lined with a black silt that reminded old timers of gun powder. Yaak is an Indian word meaning arrow, and the natives saw this stream as an arrow cutting across the arc or bow made by the Kootenai River.

Any study of town placenames will find the most specific information in post office records. These records give the best clue as to when a town was established, flourished, and when and if it died. In Montana, many of the towns did die. Of the 1,900 places in the state that at one time reached the status of having post offices, only about 300 remain. Also, the designation of a "post office" did not always indicate the existence of a town. The "office" was apt to be a cigar box in a prospector's cabin, or a shoebox in a settler's kitchen. Sometimes there was enough mail to justify an apple box on a homesteader's back porch. Fort Owen used a beer bottle case nailed to the wall for boxes.

The earliest post offices in Montana were, of course, in the gold strike areas: Bannack in 1863, Hell Gate in 1862, Virginia City in 1864, and Gold Creek in 1886. Mail came by stagecoach, freight wagon, or by horseback. Stagecoach stations often served as mail drops even before offices were established by the federal government. Post offices came and went with the fate of mining camps. Junction City, Adobetown, Nevada City, and Central City - all within a few miles of Virginia City - at one time had post offices of their own. Neihart was a mining town in the Little Belt Mountains; mail came by horseback from White Sulphur Springs. The mail sack going either direction, to Neihart or to White Sulphur Springs, was hung on the branch of a tree, and anyone coming or going was duty bound to take it along. One sack of mail took from November to June to make this forty-two mile trip. 
Iron Rod, a camp originally called Ragtown, got its new name when a fancy bridge made of iron was built across the Jefferson River to replace a rickety old wooden one. When an agent from Philadelphia came to inspect Montana post offices in 1873, the Iron Rod post office was in the back room of the saloon. It was mail day at Iron Rod and the big bag was brought in. The contents were dumped on the floor, and patrons on hands and knees scrambled to look for letters. After they were finished, the remaining letters were shoveled into a candle box and put on the end of the bar. The special agent, thinking the office needed some regulating, asked the bartender if he were the postmaster. "Hell, no," he barked, "he's gone up the canyon, but Bill Jones has got to run this office next week; it's his turn." Whereupon the inspector asked for the keys to the office. The bartender put the candle box on the floor, gave it a kick, and said "There's your office ... now git," and, said the inspector in reporting the incident to the Philadelphia Ledger, "knowing the customs of the country... I got" (Montana Magazine of History).

Utica began in the 1880 s as a lively meeting place in the spring and fall for central Montana cowboys, but it was cold and lonely in the dead of winter. After having shivered out a winter, four early settlers joked that a man had to be crazy to live there year around. When asked for a name on their post office application, they suggested Utica, which was the location of the insane asylum in their home state of New York. Greenhorn was a mining camp in the Helena area and had a post office from 1871 to 1873 . The office opened again in 1882, but in April of the next year the Territorial Governor of Montana telegraphed the postal authorities in Washington, D.C. :

\section{VIGILANTES AT GREENHORN, MONTANA, HAVE REMOVED POSTMASTER BY HANGING. OFFICE NOW VACANT.}

The office never reopened. Evidently no one wanted to take his place (Cheney 126). A "greenhorn" was anyone from the East who was unaccustomed to Western ways.

The Homestead Act and the promotion by railroads brought a rash of post offices and new names. Often when the settlers had unloaded their wagons and gotten a few acres plowed and planted, they began to be lonesome for news from home. One man, or more likely a woman, 


\section{Roberta Cheney}

carried a petition around and got the required number of signatures and offered to be the postmaster. Since the "office" was almost always in some homesteader's home, for the sake of convenience his family name generally became the name of the office and later the town. The "office" moved from one tar paper shack to another until someone opened up a general store in the community and took over the mail service, or until the railroad parked a box car along the tracks in the area and called it a station, thus starting a town and locating the post office. Two hundred and forty-six towns in Montana were named for their first postmasters. Clearly, this process was one of the primary naming mechanisms.

However, the largest category of Montana placenames is the one that includes towns named for residents of the area other than postmasters. Over twenty percent of the names (333) were taken directly from a local person's name. In most cases the name is used in its original form. Sometimes a suffix was added; -ville was a favorite one. City was often added to the name of a mining camp. It added a bit of dignity. However, only Miles City (after General Nelson A. Miles) and Virginia City have retained this generic designation.

From the long list of commemorative placenames, one can identify the nationalities that went into the frontier crucible to make Montana: O'Neill and Kelly; McLeod and McDonald; Paterson and Andersonville; Story and Brooks; Reichle and Robare; Hauck and Kessler; Kilz and Gebo. Of the counties, twenty-six were named for men: Blaine, Broadwater, Chouteau, Custer, Dawson, Fallon, Fergus, Gallatin, Hill, Jefferson, Ravalli, Sanders, Sheridan, Toole, Wibaux, Carter, Daniels, Garfield, Lewis and Clark, Lincoln, McCone, Madison, Meagher, Phillips, Powell, and Roosevelt. Of the twenty-seven men thus honored, sixteen were national figures and eleven were prominent men within the state.

Twenty-seven counties have names of animal, geographic, or idealistic origin: Beaverhead, Big Horn, Carbon, Cascade, Granite, Mineral, Musselshell, Park, Prairie, Rosebud, Richland, Silver Bow, Stillwater, Sweetgrass, Valley, Yellowstone, Golden Valley, Teton, Powder River, Treasure, Liberty, Lake, Glacier, Judith Basin (combination of a person's name and a geographical feature-also the only county named for a woman), Petroleum, and Pondera. The last was descriptive from the French Pend d'Oreille, meaning hanging ear, but it could also be classified with the Indian origins as mentioned earlier. 
Placenames give a comprehensive picture of the animals and plants that were here before the white men came. Wolf Creek, Bear Creek, Buffalo, Alder Gulch, Cottonwood Creek, and Rosebud to name only a few. Creeks, even more than towns, were named for plants or animals in the area.

There is a natural poetry in the Sound of American names. . Read the names of the towns and cities, of the creeks and rivers... read them aloud ... there is a pattern that is a kind of folk music in itself, rich in human and historical associations, rich in humor, alive with a beauty that is sometimes smooth and singing and sometimes keen as a trapper's knife. (Life Magazine)

In this sense, Montana's names are a poetry of its history, people, and landscape.

Cameron, Montana

\title{
Works Cited
}

Cheney, Roberta C. Names on the Face of Montana. 2nd ed. Missoula: Mountain Press, 1983.

Guthrie, A. B., Jr. The Big Sky. Boston: Houghton Mifflin, 1965.

Life Magazine. January 31, 1938.

Montana Magazine of History. January 1953.

\section{$* * * * *$ \\ Christopher Columbus 1492-1992}

October 12, 1992, will mark the 500th anniversary of Columbus' landfall in the New World. Names will join the rest of America in recognizing this significant occasion with a special issue (September 1992) devoted to onomastic topics relating to Columbus and his legacy. Probable deadline for submission of papers: November 1991. For further information contact:

\author{
Thomas J. Gasque, Editor \\ Names \\ Department of English \\ University of South Dakota \\ Vermillion, SD 57069
}




\section{ANS at MLA}

The American Name Society will hold two sessions at the annual meeting of the Modern Language Association in Washington, DC, December 27-30, 1989.

One session, chaired by Grace Alvarez-Altman, will focus on Literary Onomastics and will include papers by Joel L. Brattin, "Giving Names and Taking Names Away in The Red Badge of Courage"; Zacharias P. Thundy, "The Name of the Rose"; Grant Smith, "Art and Names in Shakespeare's Tempest"; and Claire A. Culle,ton, "Names, Identities, and Eternal Incognitoes: The Burden of Patriarchal Onomasty in Women's Expatriate Writing."

The other session, chaired by Wayne $\mathrm{H}$. Finke, will feature Names in Literature and Folklore, with papers by Leonard R.N. Ashley, “"Marked Days' in Norwegian Life and Folk Etymology"; Randy Prus, "Ishmael's Spirit Spout: Mythology and Geography in Moby Dick"; Thomas J. Gasque, "An Onomastic Odyssey in Europe"; and Roland Dickison, "Black Bart, Who the Man, Whence the Name?"

In addition, the American Name Society will hold special sessions, a business meeting, and a banquet. Watch for announcements of times and places. 